Sains Malaysiana 50(3)(2021): 629-644

http://dx.doi.org/10.17576/jsm-2021-5003-06

\title{
Long Term Trend Analysis of Upstream and Middle-Stream River in Langat Basin, Selangor, Malaysia
}

(Analisis Tren Jangka Panjang Huluan dan Aliran Tengah Sungai di Lembangan Langat, Selangor, Malaysia)

\author{
Siti Hawa Mohd Yusoff, Firdaus Mohamad Hamzah*, Othman JaAfar \& Hazrina Tajudin
}

\begin{abstract}
The present study investigates the trend in long term monthly streamflow of Sungai Lui (upstream) and Sungai Kajang (middle-stream) of the Sungai Langat Basin located in Selangor, Malaysia. The Mann-Kendall (MK) and Innovative Trend Method (ITM) tests were utilized to assess the trends at the two stations. The trend free pre-whitening (TFPW) and variance correction (VC) tests were used to assess the effects of serial correlation on the established trend, and Sen's slope estimator was used to assess the magnitude of streamflow. Based on Sen's Slope estimator results, the trend magnitude for Lui station is very small compared to the Kajang station. The Kajang station shows the highest increase in trend magnitude for November. The results of TFPW and VC trend tests showed that the most significant increasing trend of months occurred at Kajang station, while the less increasing significant trend of months occurred at Lui station. It can be concluded that similar trend results were obtained when the modified Mann-Kendall and ITM were applied to the same data for Sungai Lui and Sungai Kajang. The study found that there is a significant difference in terms of trend and magnitud between upstream and middle-stream.
\end{abstract}

Keywords: Innovative trend method; Mann-Kendall; Sen's slope; trend free pre-whitening; variance correction

ABSTRAK

Kajian dilakukan terhadap tren aliran bulanan jangka panjang bagi Sungai Lui (aliran hulu) dan Sungai Kajang (aliran tengah) di Lembangan Sungai Langat yang terletak di Selangor, Malaysia. Ujian Mann-Kendall (MK) dan Kaedah Inovatif Tren (ITM) digunakan untuk menilai tren aliran di kedua-dua stesen tersebut. Ujian pra-pemutihan bebas tren (TFPW) dan pembetulan varians (VC) digunakan untuk menilai kesan korelasi bersiri pada tren dan penganggar cerun Sen digunakan untuk menilai magnitud aliran sungai. Berdasarkan hasil penganggar cerun Sen, magnitud tren untuk stesen Lui sangat kecil berbanding dengan stesen Kajang. Stesen Kajang menunjukkan peningkatan tren magnitud tertinggi untuk bulan November. Hasil ujian tren TFPW dan VC menunjukkan bahawa peningkatan tren bulanan yang paling ketara berlaku di stesen Kajang, sementara peningkatan tren bulanan yang kurang ketara berlaku di stesen Lui. Ia dapat disimpulkan bahawa hasil keputusan tren yang sama diperoleh apabila kaedah modifikasi Mann-Kendall dan ITM diterapkan pada data yang sama untuk Sungai Lui dan Sungai Kajang. Kajian ini mendapati bahawa terdapat perbezaan yang signifikan daripada segi tren dan magnitud aliran di antara aliran hulu dan aliran tengah.

Kata kunci: Cerun Sen; kaedah innovatif tren; Mann-Kendall; pembetulan varians; ujian tren pra-pemutihan

\section{INTRODUCTION}

Many studies of varying scales have been conducted at many different locations to determine streamflow trend and other climatic variables. Increasing variation in streamflow due to the changing climate has altered the hydrological cycle. These changes may be gradual (trend) or abrupt (shift). Geographical factors (i.e. freshwater area, elevation, urbanization, and proximity to coast) and climatic factors (i.e. air temperature, wind speed, relative humidity, and solar radiation) are among the factors that influence the hydrological cycle (Rim 2017). Also, watersheds under similar climate and soils conditions, topography and land use could be the primary factors determining the streamflow response to precipitation (Wang et al. 2018). Previous studies have found that pastures or agricultural lands could have higher streamflow yields and amplitude, while forests generally have lower water yield compared with pastures (Cristina et al. 2015). These hydrological changes may lead to the under-designed or over-designed of projects (Sagarika et al. 2014). 
The majority of previous hydrological studies used non-parametric techniques, especially the Mann-Kendall trend test and Sen's slope estimator statistical tools. These tests are robust against outliers, distribution free and are not sensitive to abrupt breaks in the time series (Chen et al. 2016; Hamzah et al. 2017; Rahman et al. 2017; Sa et al. 2017; Zhao et al. 2015). The magnitude (slope) of trend can be computed by using the slope estimator proposed by Sen (1968). Sen's slope estimator has been widely used in hydro-meteorological time series (da Silva et al. 2015; Mustapha 2013; Thenmozhi \& Kottiswaran 2016).

On the other hand, the serial correlation needs to be performed before performing the Mann-Kendall trend test. The effect of serial correlation has to be taken into account since the Mann-Kendall trend test assumes that the sample data are serially independent (Azam et al. 2018; Diop et al. 2017). Note that $\alpha$ (the significance level) is the tolerable probability that the Mann-Kendall trend test will falsely reject the null hypothesis. Falsely rejecting the true null hypothesis is called a Type I error. The probability of Type I error is decreased when the data are independent. The presence of a positive serial dependence would increase the probability of rejecting the no-trend hypothesis (Bayazit \& Önöz 2009), and the trend may be incorrectly estimated (Chattopadhyay \& Edwards 2016). To overcome this problem, Yue and Wang (2002) and Yue et al. (2002) applied the Trend Free Pre-Whitening method to the data series, where the serial correlation was firstly removed and the trend test was then performed on the uncorrelated residuals (Hajani et al. 2017; Piyoosh $\&$ Ghosh 2017). Furthermore, Hamed and Rao (1998) introduced the modified Mann-Kendall trend test through the variance correction approach to account for the effect of serial correlation (Salman et al. 2017). Recently, the innovative trend method (ITM) proposed by Sen (2012) has been successfully applied in the hydrological time series. This new method does not impose any restriction and can be utilized whether the time series is serially correlated, non-normally distributed, or has a short record length. It can also be grouped into low, medium, and high, which facilitates the identification of the pattern of trend (Ay \& Kisi 2015; Kisi et al. 2018; Sen 2014; Terzioglu et al. 2019).

In Malaysia, the study on streamflow or rainfall trend is becoming increasingly important in an effort to evaluate the hydrological pattern for future flood assessment since flood is the most common natural disaster in Malaysia. The misuse of natural resources in Malaysia, such as uncontrolled discharge of pollution, energy development projects, development of livestock production, and massive land reclamation, may have contributed to the occurrences of flood events, stream degradation, and erosion (Sulaiman et al. 2015). Numerous studies on climatic or hydrological parameters have been conducted using different methods. Trend tests such as Mann-Kendall and Sen's slope estimator have been widely used in the analysis of streamflow (Ebrahimian et al. 2018; Jan et al. 2018; Rao et al. 2011), rainfall (Palizdan et al. 2015, 2014; Sa et al. 2017), temperature (Amirabadizadeh et al. 2015) and water quality (Samsudin et al. 2017). Therefore, the main purpose of this study was to present a trend analysis of the streamflow of Sungai Langat Basin in Selangor, Malaysia. The trend analysis is very important for water resources planning, design and management in that area.

\section{METHODS}

\section{STUDY AREA AND DATA SET}

The map in Figure 1 shows the location of Sungai Langat located in the state of Selangor, Malaysia. The Sungai Langat basin has a total catchment area of approximately $1815 \mathrm{~km}^{2}$ and lies within longitude $101^{\circ} 17^{\prime} \mathrm{E}$ to $101^{\circ} 55^{\prime} \mathrm{E}$ and latitudes $2^{\circ} 40^{\prime} \mathrm{N}$ to $3^{\circ} 17^{\prime} \mathrm{N}$. The Sungai Langat basin is one of the most important basins which supply water to two-thirds of the state of Selangor. Sungai Langat flows from the Titiwangsa Range in the Northeast of Hulu Langat District and drains into the Straits of Malacca. There are four gauging stations along Sungai Langat, namely Lui (station no. 3118445), Kajang (station no. 2917401), Semenyih (station no. 2918401), and Dengkil (station no. 2816441) stations (respectively. The important parameters selected for the study were river flowrate, precipitation distribution, and the baseflow (Hamzah et al. 2019; Yang et al. 2011).

The map in Figure 1 shows the location of Sungai Lui station and Sungai Kajang station. Table 1 shows that there are two streamflow gauging stations along with Sungai Langat basin. Sungai Lui station (station no. 3118445) at $\mathrm{Kg}$ Sungai Lui is an upstream river with a mean elevation of $76.8 \mathrm{~m}$. While Sungai Langat at Kajang (Sungai Kajang) (station no. 2917401) is a middle-stream river with a mean elevation of $22.9 \mathrm{~m}$. Sungai Lui and Kajang basin have different geographical characteristics and land use. Table 2 which was obtained from Memarian and Balasundram (2016), shows that Sungai Kajang basin was more urbanised and has a built-up area of 5649.90 ha compared to Sungai Lui, which has a built-up are of only $111.09 \mathrm{ha}$. Lui is a more densely forested areas (359.75 ha) while Kajang has less forested areas (112.04 ha). Table 3 shows that, during period between 1984 and 2006, 34\% of rubber plantations in the Kajang sub-basin have been transformed into urban areas and another $11 \%$ has been converted into other agricultural production. In the Lui subbasin, $21 \%$ of rubber plantations have been transformed 
into agricultural production and 5\% was transformed into urban areas. One percent of the forest area in the Lui subbasin has been transformed into rubber plantations and 5\% was transformed into urban area. In the Kajang sub-basin, $4 \%$ of the forest area has been transformed into rubber plantations and $3.5 \%$ was transformed into urban area.

The hydrological characteristics of Sungai Langat are greatly influenced by two heavy rainy seasons during the South-West (May - September) and North-East (November - March) monsoons. The climate of the basin is most affected by the South-West Monsoon that blows across the Straits of Malacca. Meanwhile, convectional rainfall is a common occurrence during the inter-monsoon period. Malaysia receives a heavy rainfall of between 2000 and $3000 \mathrm{~mm}$ per year. The basin receives rainfall throughout the year; the mean annual rainfall of about $2470 \mathrm{~mm}$ and the highest amount of rainfall typically occur between March and November. The temperature is high and uniform throughout the year, with a mean annual temperature of $27{ }^{\circ} \mathrm{C}$. Sungai Langat Basin receives a high amount of precipitation which can cause extreme streamflow in the area. All streamflow data were provided by the Department of Drainage and Irrigation (DID), Malaysia.

TABLE 1. Flow gauging stations in Sungai Langat Basin

\begin{tabular}{lcccccccc}
\hline No. & Site & $\begin{array}{c}\text { Station } \\
\text { number }\end{array}$ & $\begin{array}{c}\text { Catchment area } \\
\left(\mathrm{km}^{2}\right)\end{array}$ & Latitude & Longitude & $\begin{array}{c}\text { Mean } \\
\text { elevation } \\
(\mathrm{m})\end{array}$ & $\begin{array}{c}\text { Sample } \\
\text { size } \\
\text { (years })\end{array}$ & Period of data \\
\hline 1. & Sungai Lui & 3118445 & 68.1 & $03^{\circ} 10^{\prime} 25^{\prime \prime} \mathrm{N}$ & $101^{\circ} 52^{\prime} 20^{\prime \prime} \mathrm{E}$ & 76.8 & 52 & $1965-2016$ \\
2. & Sungai Kajang & 2917401 & 389.4 & $02^{\circ} 59^{\prime} 40^{\prime \prime} \mathrm{N}$ & $101^{\circ} 47^{\prime} 10^{\prime \prime} \mathrm{E}$ & 22.9 & 39 & $1978-2016$ \\
\hline
\end{tabular}

TABLE 2. Change in land use pattern between 1984 and 2006 in the study sub-basins (Memarian \& Balasundram 2016)

\begin{tabular}{lcc}
\hline \multicolumn{1}{c}{ Land use } & Difference (2006-1984) & in hectares \\
\hline Agriculture & Lui & Kajang \\
Bare land & 436.39 & 1545.32 \\
Forest & 6.3 & 370.60 \\
Grassland & 359.75 & 112.04 \\
Marshland/swamp & 5.0 & -471.70 \\
Mining & 46.42 & 148.93 \\
Oil palm & 16.67 & 395.27 \\
Rubber & 3.44 & 21.81 \\
Urban/ Built-up areas & -809.43 & -7817.72 \\
Water body & 111.09 & 5649.90 \\
\hline
\end{tabular}


TABLE 3. Percentage of land use change matrix for important transitions between 1984 and 2006 for Lui and Kajang sub-basins (Memarian \& Balasundram 2016)

\begin{tabular}{|c|c|c|c|c|}
\hline 1984 & 2006 & & & \\
\hline & \multicolumn{4}{|c|}{ Lui } \\
\hline & Forest & Rubber & Agriculture & Urban/ industrial area \\
\hline Forest & & 1 & 1 & 1 \\
\hline Rubber & & & 21 & 5 \\
\hline \multirow[t]{2}{*}{$\begin{array}{l}\text { Scrub/idle } \\
\text { grassland }\end{array}$} & 47 & 11 & 33 & 4 \\
\hline & \multicolumn{4}{|c|}{ Kajang } \\
\hline Forest & & 4 & & 3.5 \\
\hline Rubber & & & 11 & 34 \\
\hline Agriculture & & 17 & & 26 \\
\hline $\begin{array}{l}\text { Scrub/ idle } \\
\text { grassland }\end{array}$ & 38 & 17 & 10 & 31 \\
\hline
\end{tabular}

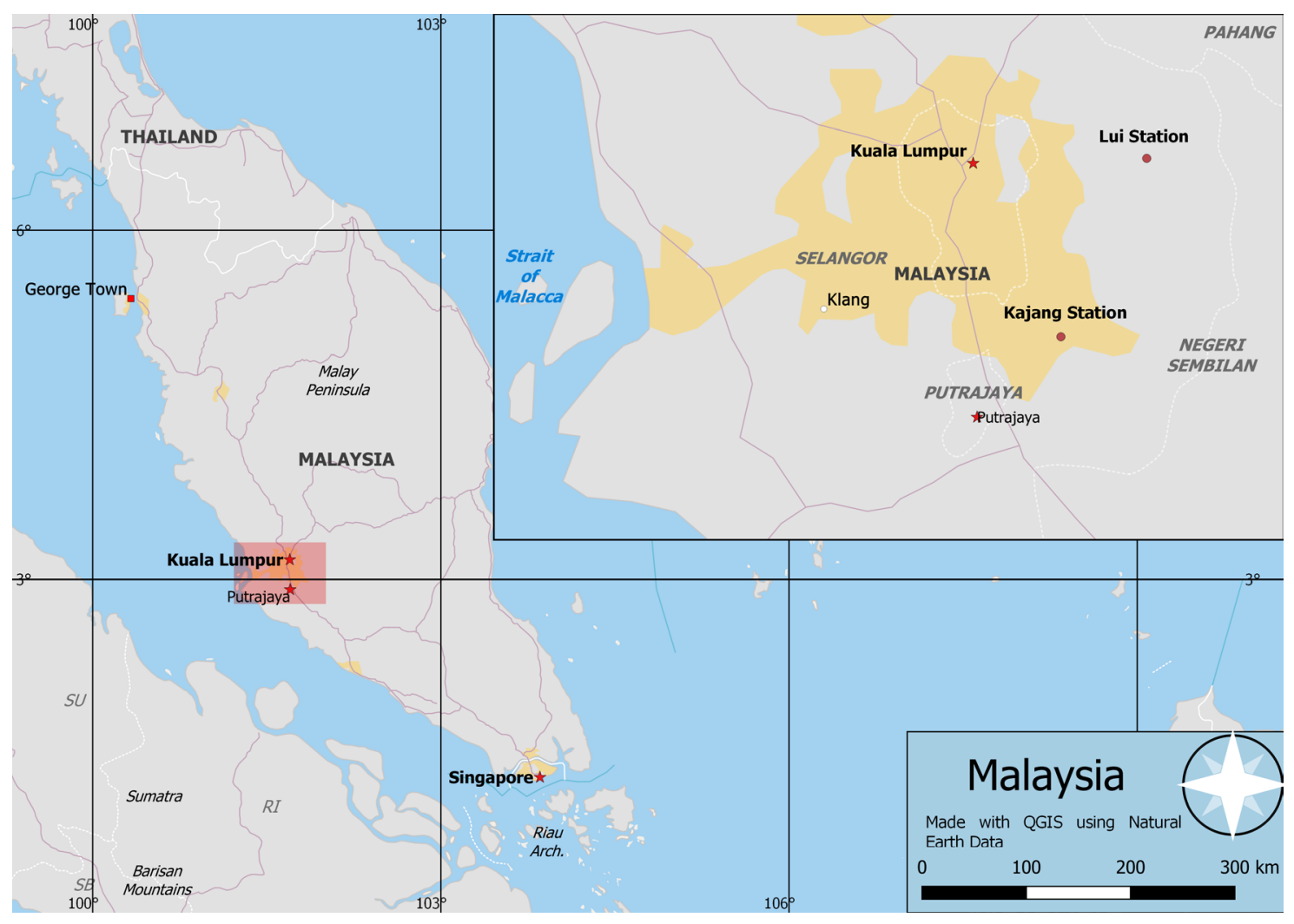

FIGURE 1. Map of the Sungai Langat basin located in Selangor, Malaysia 
MANN-KENDALL TEST

The trend for monthly streamflow was determined using a non-parametric approach, the Mann-Kendall trend test (Kendall 1957; Mann 1945). The null hypothesis, $H_{o}$, for the Mann-Kendall trend test is no monotonic trend in the series. While, the alternative hypothesis, $H_{1}$, is there is an increasing or decreasing trend in streamflow over time at a given $\alpha$ significance level (Gavrilov et al. 2016; Önöz \& Bayazit 2003). The following formula is used in the Mann-Kendall trend test.

$$
\begin{gathered}
T_{M K}=\frac{S-\operatorname{sgn}(S)}{\sqrt{V(S)}} \\
s=\sum_{i=1}^{n-1} \sum_{j=i+1}^{n} \operatorname{sgn}\left(x_{j}-x_{i}\right)
\end{gathered}
$$

where $n$ is the number of data points; $x_{j}$ and $x_{i}$ are the data value in the time series; $i$ and $j$ are the total data set; and $\operatorname{sgn}\left(x_{j}-x_{i}\right)$ is the sign function which is calculated as follows:

$$
\operatorname{sgn}\left(x_{j}-x_{i}\right)=\left\{\begin{aligned}
+1, & \text { if }\left(x_{j}-x_{i}\right)>0 \\
0, & \text { if }\left(x_{j}-x_{i}\right)=0 \\
-1, & \text { if }\left(x_{j}-x_{i}\right)<0
\end{aligned}\right.
$$

The variance is calculated using the following formula:

$$
\begin{gathered}
E(S)=0 \\
V(S)=\left[n(n-1)(2 n+5)-\sum_{k=1}^{m} t_{k}\left(t_{k}-1\right)\left(2 t_{k}+5\right)\right] / 18
\end{gathered}
$$

where $t_{k}$ is the total bonding point $k$. The standard statistical test $z$ is calculated as follows:

$$
z_{S}=\left\{\begin{aligned}
\frac{s-1}{\sqrt{V(S)}}, & \text { if } S>0 \\
0, & \text { if } S=0 \\
\frac{s-1}{\sqrt{V(S)},} & \text { if } S<0
\end{aligned}\right.
$$

The standard statistical Mann-Kendall $z$ is a standard normal distribution with a mean $\mu=0$ and a standard deviation $\sigma=1$. A positive $z$ value indicates an increasing trend in the streamflow time series data while a negative value indicates a decreasing trend. $\mathrm{H}_{0}$ is rejected if the value of $|z|$ is higher than the significance value of $z_{\alpha / 2}$ and thus it can be concluded that there is a significant trend. A significance value, $\alpha$, of 0.05 is selected in this study, which give a critical value of 1.96 in the standard normal table (Rahman et al. 2017).

TREND FREE PRE-WHITENING METHOD

To reduce the effect of serial correlation, Yue et al. (2002) proposed a trend free pre-whitening (TFPW) of the time series before conducting the trend test. The main steps to in TFPW are as follows:

Step 1 The lag-1 auto-correlation coefficient is estimated and removed from the detrended series by using (7).

$$
Y_{i}=X_{i-b t}
$$

where $Y_{i}$ is the pre-whitening time series data being examined; and $X$ is the original time series data.

Step 2 Estimate median slope, $b$, using the Sen approach, Equation (13), and remove the slope of the trend from the original series.

Step 3 The estimated slope is superimposed onto the last series, and is referred to as the blended series.

\section{VARIANCE CORRECTION APPROACH}

Hamed and Rao (1998) proposed using the variance correction of the Mann-Kendall test statistic to reduce the effect of serial independence. The variance has to be modified by using the following equation:

$$
\operatorname{Var}(S)^{*}=\operatorname{Var}(S) \cdot \frac{n}{n^{*}}
$$

where $\operatorname{Var}(S)^{*}$ is the modified variance; $\operatorname{Var}(S)$ is the variance of Mann-Kendall before modification, $n$ is sample size, and $n^{*}$ is effective sample size.

$$
n *=\frac{n}{1+2 \sum_{k=1}^{n-1}\left(1-\frac{k}{n}\right) \cdot r_{k}}
$$

where $r_{k}$ is the significant lag- $k$ serial correlation coefficient given by the following equations:

$$
\begin{gathered}
\frac{\frac{1}{n-k} \sum_{t=1}^{n-k}\left[X_{t}-\left(\frac{1}{n} \sum_{t=1}^{n} X_{t}\right)\right]\left[X_{t+k}-\left(\frac{1}{n} \sum_{t=1}^{n} X_{t}\right)\right]}{\frac{1}{n} \sum_{t=1}^{n}\left[X_{t}-\left(\frac{1}{n} \sum_{t=1}^{n} X_{t}\right)\right]^{2}} \\
Z_{C}=\left\{\begin{array}{cc}
\frac{S-1}{\sqrt{\operatorname{Var}(S)^{*}}} & \text { if } S>0 \\
0 & \text { if } S=0 \\
\frac{S+1}{\sqrt{\operatorname{Var}(S)^{*}}} & \text { if } S<0
\end{array}\right.
\end{gathered}
$$

\section{SEN'S SLOPE ESTIMATOR}

Sen's slope estimator was developed by Sen (1968) and is a non-parametric procedure for estimating the slope of a trend. The linear model for can be expressed as

$$
f(t)=Q t+\beta
$$

where $Q$ is slope; $\beta$ is a constant; and $t$ is time. To derive the estimate of $Q$, the slope of all data pairs is calculated using (13). 


$$
Q_{i}=\frac{x_{j}-x_{k}}{j-k}, \quad i=1,2, \ldots, n
$$

where $x_{j}$ and $x_{k}$ are the data values at times $j$ and $k,(j>k)$, respectively. If there are $n$ values $x_{j}$ in the time series then the Sen slope estimator is the median of $n(n-1) / 2$ pairwise slopes; hence the Sen slope estimator is calculated using (14):

$$
Q_{\text {med }}=\left\{\begin{array}{cc}
\frac{Q_{\frac{n+1}{2}},}{2}, & \text { if } n \text { is odd } \\
\frac{Q_{n / 2}+Q_{(n+2) / 2},}{2}, & \text { if } n \text { is even }
\end{array}\right.
$$

\section{INNOVATIVE TREND METHOD}

The innovative trend analysis methodology principles were proposed by Sen $(2014,2012)$ for identifying the partial trend components in 'low', 'medium' and 'high' data values. The graph that demonstrate the possible partial trends (Oztopal \& Sen 2017) is obtained as follows. Divide the main time series into two equal parts. For example, the time series has 100 observations, then the first half sub-series is the first 50 observations and the second half sub-series consists of the next 50 observations. Sort each sub-series into ascending order. The first half of sub-series is plotted on the $\mathrm{x}$-axis, while the second half of the sub-series is plotted on the y-axis of the Cartesian coordinate system. Draw a $45^{\circ}$ or $1: 1$ straight line on the same Cartesian coordinate system; this line theoretically indicates that there is no trend in a given series. Identify the sub-group in the scatter diagram, which are the 'low', 'medium' and 'high' value groups.
Compare each group with the 1:1 straight-line and make the following decisions: If the sub-group or data points are close or fall within $\pm 5 \%$ of the $1: 1$ line or at the maximum $\pm 10 \%$ error then there is no trend in the time series. If the sub-group or data points are fall over the 1:1 line, then there is an increasing trend in the group. If the sub-group or data points are fall below the 1:1 line, then there is a decreasing trend in the group.

\section{RESULTS AND DISCUSSION}

\section{STATISTICAL CHARACTERISTICS OF STREAMFLOW}

This section discusses the results of analysis for the two gauging stations in Sungai Langat basin. Lui station represents the upper stream and has a mean elevation of $76.8 \mathrm{~m}$ from the datum, while Kajang station represents the lower stream and has a mean elevation of $22.9 \mathrm{~m}$ from the datum. The plot of monthly average streamflow is presented in Figure 2. The figure shows that the lowest average monthly streamflow occurred in February, July, and August while the high streamflow occurred in April, October, November, and December, with the highest streamflow recorded in November. This is because the climate in Peninsular Malaysia is influenced by two monsoon seasons and two inter-monsoon periods. A previous study has shown that long-term changes in annual streamflow were influenced by the variation in precipitation (Zhang et al. 2008). A study by Mayowa et al. (2015) and Palizdan et al. (2015) has shown that high intensity rainfalls occur during the March-April and October-November inter-monsoon period.

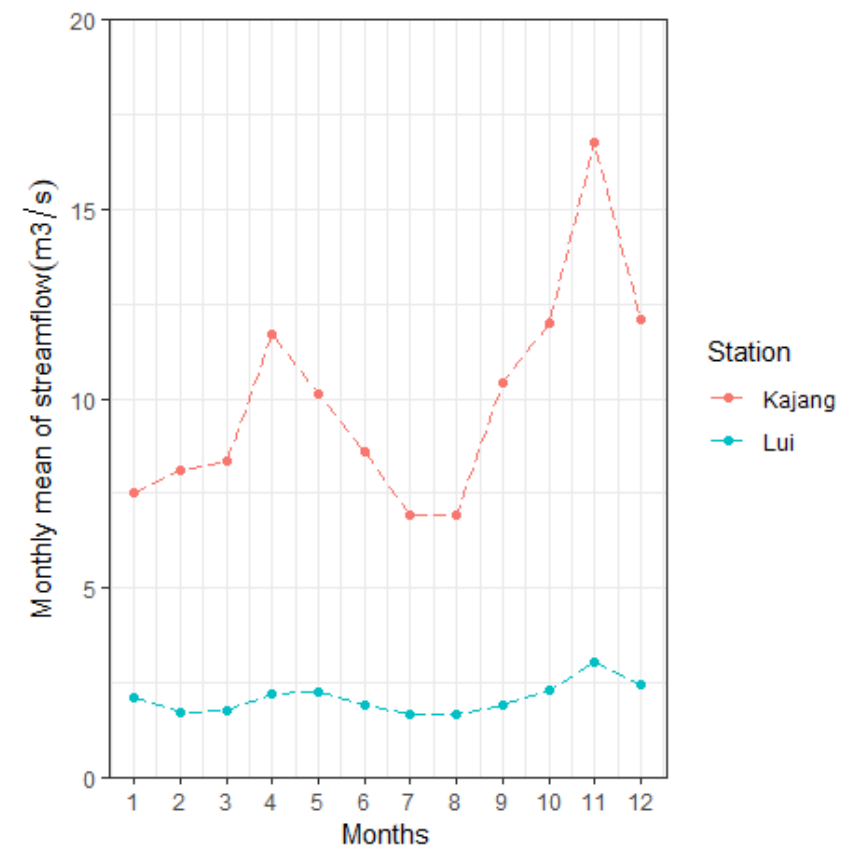

FIGURE 2. Monthly mean streamflow at the Lui and Kajang gauging stations 

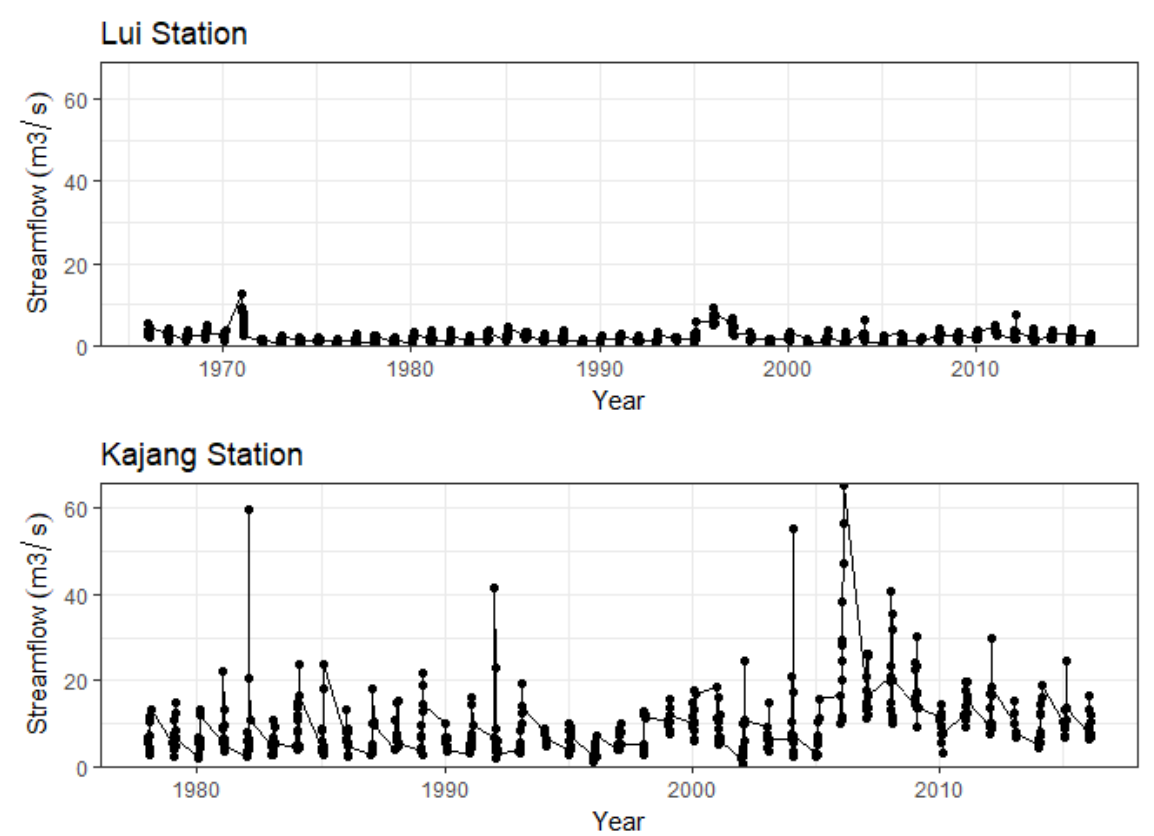

FIGURE 3. The streamflow time series for Sungai Lui (1965-2016) and Sungai Kajang

(1978-2016)

Figure 3 shows the streamflow time series for Sungai Lui for the period from 1965 to 2016. The graph shows that the streamflow fluctuates slightly with the highest streamflow reading of $12.64 \mathrm{~m}^{3} / \mathrm{s}$ recorded in 1971. The plot for Sungai Kajang is for the period from 1978 to 2016 . The graph shows a marked fluctuation in streamflow with the highest monthly streamflow of $65.39 \mathrm{~m}^{3} / \mathrm{s}$ recorded in 2006 , followed by the second highest monthly streamflow of $58.81 \mathrm{~m}^{3} / \mathrm{s}$ in 1982 . Table
4 presents the description of monthly streamflow for both stations. Sungai Lui has a mean streamflow of $1.699 \mathrm{~m}^{3} / \mathrm{s}$ and standard deviation of $1.423 \mathrm{~m}^{3} / \mathrm{s}$. The small difference between the values of the standard deviation and the mean implies that the spread of data is small. In contrast, Sungai Kajang has a large standard deviation of $7.879 \mathrm{~m}^{3} / \mathrm{s}$ in comparison to the mean value of $5.308 \mathrm{~m}^{3} / \mathrm{s}$; this indicates that the data are more spread out and the occurrence of more extreme streamflow.

TABLE 4. Description of Lui and Kajang streamflow data

\begin{tabular}{ccccccccc}
\hline No. & Station & Minimum & Maximum & $1^{\text {st }}$ Quartile & Median & $3^{\text {rd }}$ Quartile & Mean & $\begin{array}{c}\text { Standard } \\
\text { deviation }\end{array}$ \\
\hline 1 & Lui & 0.190 & 12.640 & 1.228 & 1.699 & 2.553 & 2.070 & 1.423 \\
2 & Kajang & 0.940 & 65.390 & 5.308 & 7.680 & 12.060 & 9.960 & 7.879 \\
\hline
\end{tabular}

\section{AUTOCORRELATION FUNCTION}

Before processing the data for trend test analysis, it is of crucial importance to establish the presence of a serial correlation. Since the Mann-Kendall test is designed for serial independent series, it is very critical to test for autocorrelation to prevent Type I error from occurring during the analysis. Figure 4 shows the autocorrelation function (ACF) plot for the monthly time scale streamflow series for Lui and Kajang stations located in the Sungai Langat basin, with varies sample sizes which is Sungai Lui has 52 years of record and Sungai Kajang 39 years of record. The autocorrelation is significant at the $5 \%$ level for the Sungai Lui and Sungai Kajang. Based on Figure 5 , it can be concluded that, statistically, some series are 
autocorrelated at $5 \%$ level of significance at certain lags. The blue dotted lines are the boundary for $95 \%$ confidence interval. For example, the autocorrelations for Lui and Kajang stations are significant at 5\% at lags 1, 2 and 3. Figure 5 shows the ACF plot from January to December for Lui station. The monthly streamflow exhibited a significant autocorrelation at 5\% at lag 1 for May and December, but the autocorrelation for other months are not significant. Figure 6 shows the ACF plot for Kajang station from January to December. The autocorrelation is significant at lags 1 to 3 for most of the months, with the exception of August, September, and December which did not show any streamflow autocorrelation. Since there is a significant serial correlations in the monthly streamflow time series, the effect of the serial correlations has to be eliminated by using the trend free pre-whitening technique proposed by Yue et al. (2002) and the variance correction approach proposed by Hamed and Rao (1998). The Mann-Kendall without autocorrelation was also tested for all months for the Lui and Kajang stations. The purpose of the tests is to compare the differences in the final results. The result of ACF for each month is presented in Table 5 for Lui station and Table 6 for Kajang station.

Lui

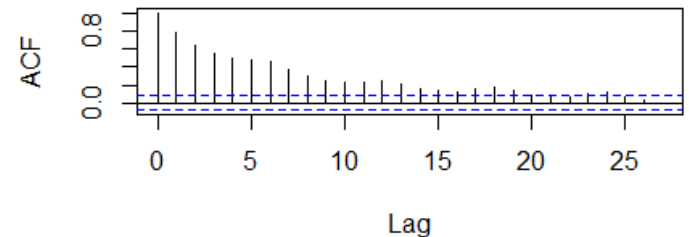

Kajang

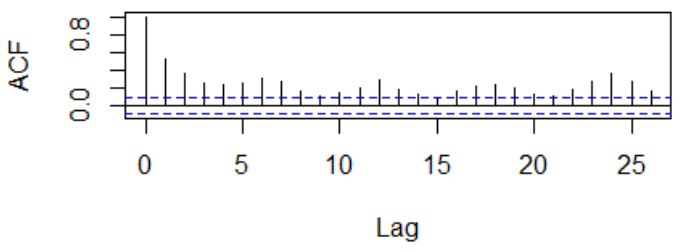

FIGURE 4. Autocorrelation function (ACF) plot of the monthly streamflow series of Lui (1965-2016) and Kajang (1978-2016) stations in Sungai Langat basin with the 95\% confidence interval indicated with the dotted lines

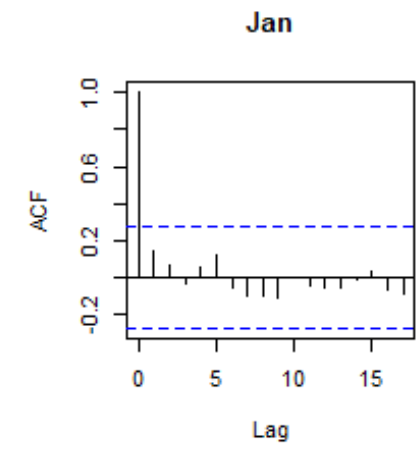

Apr

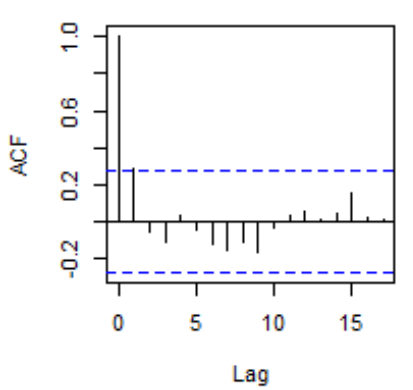

Feb

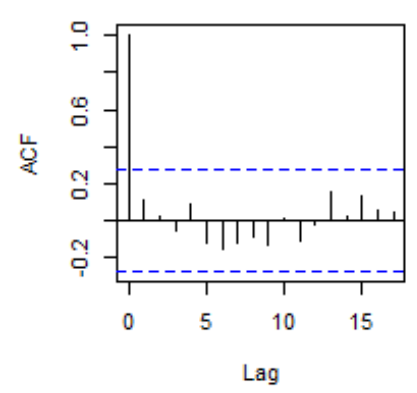

May

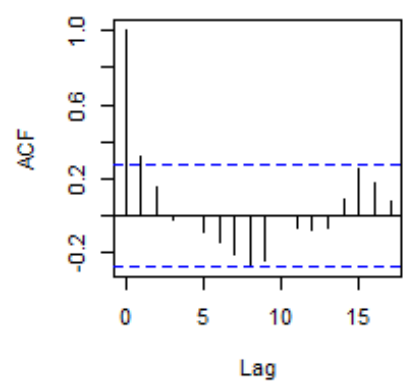

Mar

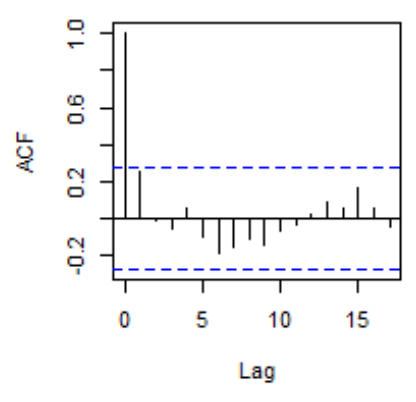

Jun

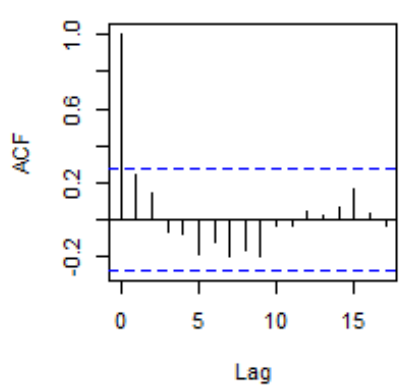



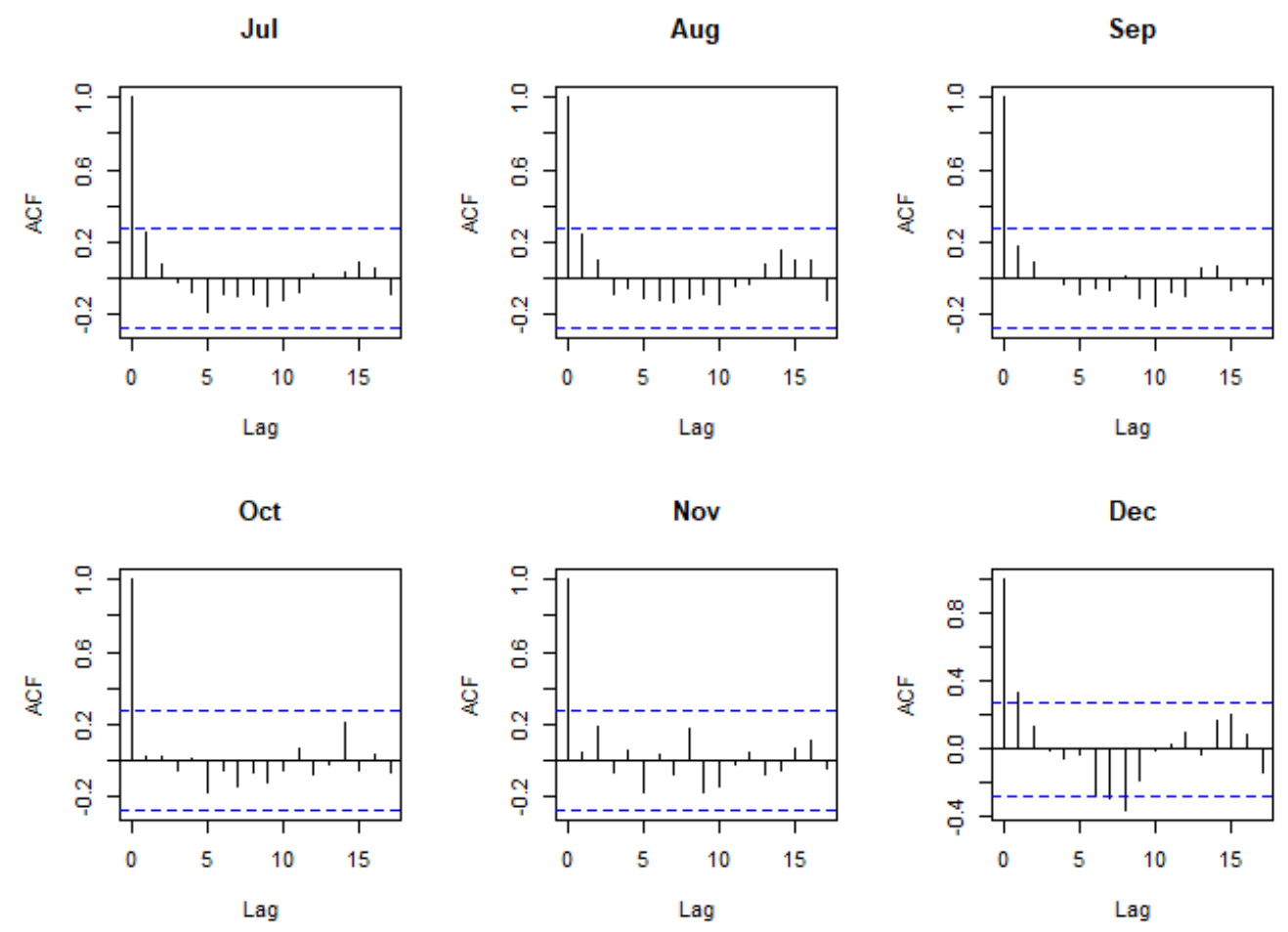

FIGURE 5. Autocorrelation function (ACF) plot from January to December for Lui station
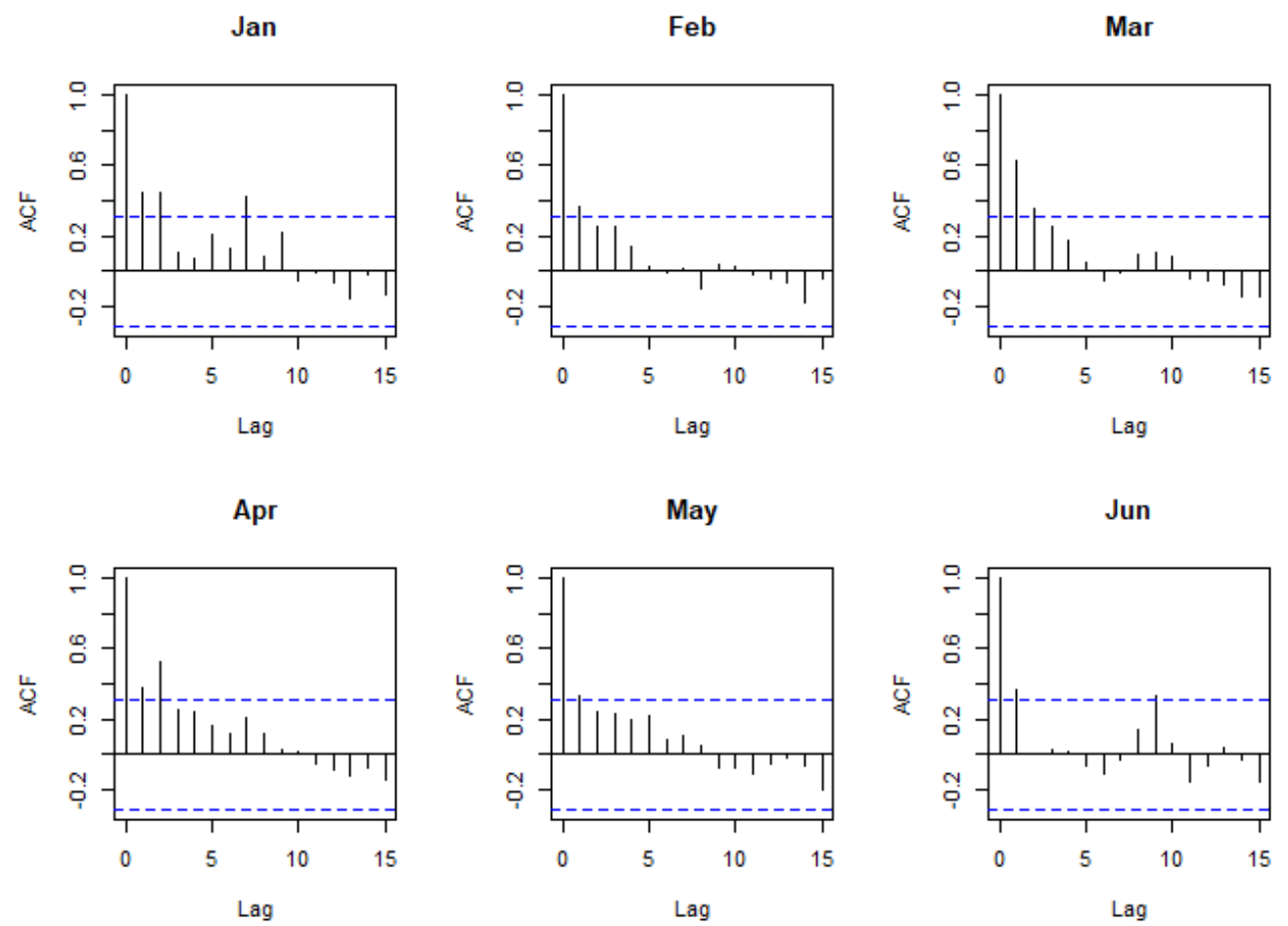
Jul

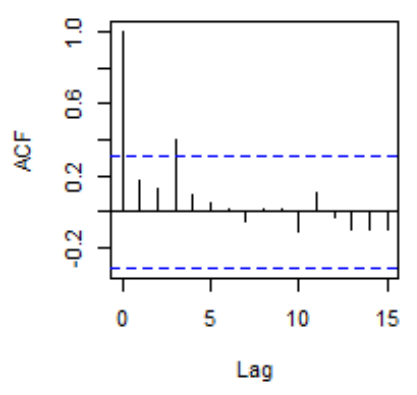

Oct

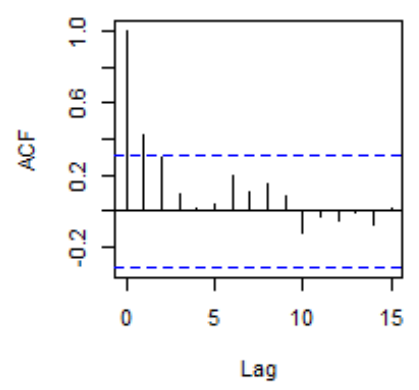

Aug

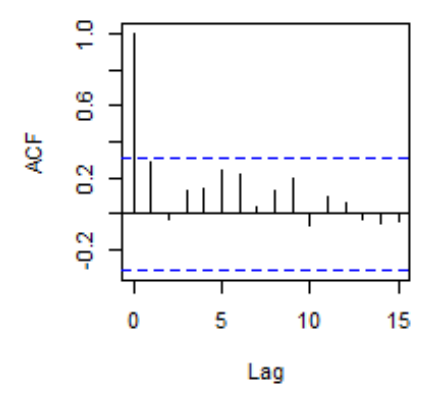

Nov

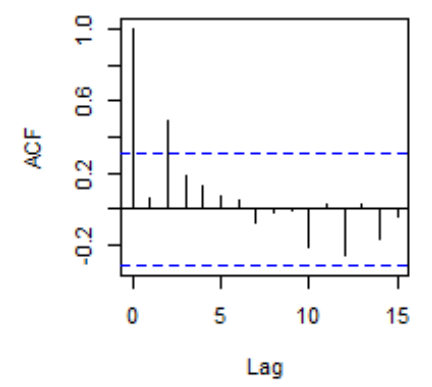

Sep

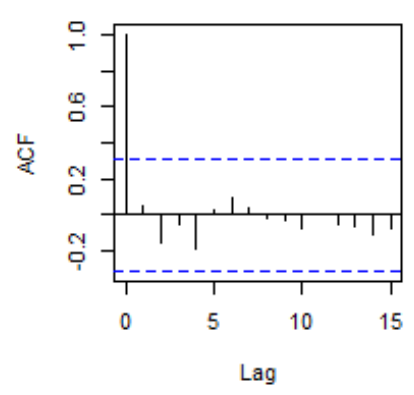

Dec

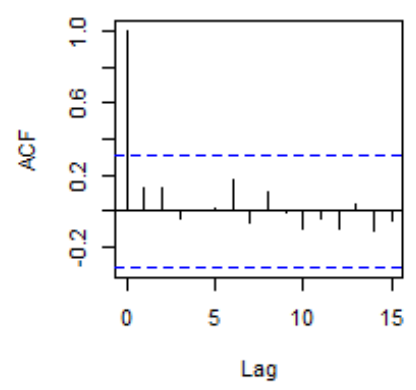

FIGURE 6. Autocorrelation function (ACF) plot from January to December for Kajang station

\section{MANN-KENDALL TREND TEST}

A comparative study between the Mann-Kendall trend test, trend free pre-whitening and variance correction approach shows that the trends are influenced by the selected gauging station, annual or monthly data series, sample size and consideration of autocorrelation structure. This is shown in Tables 3 and 4. The result of Mann-Kendall trend test which did not take autocorrelation into account after taking into account serial independence (trend free pre-whitening and variance correction approach) for the monthly streamflow time series are presented in Tables 3 and 4. The Mann-Kendall trend test was conducted to check the null hypothesis that there no trend (no change in the mean of the time series), whereas the alternative hypothesis is to test the existence of trend, whether the trend is decrease or increase in the mean of the time series. Table 3 shows the result for Mann-Kendall test ( $\mathrm{p}$-value = 0.041 ) for Lui station, where the annually streamflow series shows statistically significant increasing trend at 5\% level. The result for trend free pre-whitening method show the significant increasing trend in the months of January and annual series streamflow while the variance correction approaches did not show any significant trend for any month or annual streamflow series. The results for the streamflow at Kajang station presented in Table 4 shows that there is an increasing trend for the annual streamflow. The result for the variance correction approach shows that the trend is significantly increasing at 5\% level for the months of January, April, August, October, November, December and the annually series streamflow. The results for the Mann-Kendall and trend free pre-whitening method show that two other months, March and May, showed a significant increasing trend. The consideration of only 1-lag autocorrelation (trend free pre-whitening) is not sufficient to remove all significant serial correlation in the data series compared to complete autocorrelation (variance correction) which gives a different result for the significance of a trend. Performing the Mann-Kendall trend test without considering autocorrelation resulted in an overestimation of a significantly decreasing/increasing trend, and it should be avoided. 
TABLE 5. Result for pre-whitening, trend free pre-whitening and variance correction and Sen's slope at 95\% confidence level $(\alpha=0.05)$ for the monthly streamflow at Lui station

\begin{tabular}{lccccccc}
\hline \multirow{2}{*}{ Month } & \multicolumn{2}{c}{ Mann-Kendall } & \multicolumn{2}{c}{ Trend free pre-whitening } & \multicolumn{2}{c}{ Variance correction } & \multicolumn{2}{c}{ Sen's slope } \\
\cline { 2 - 7 } Jan & Z-value & P-value & Z-value & P-value & Z-value & P-value & Magnitude \\
Feb & 0.171 & 0.077 & 2.493 & $0.013^{*}$ & 1.355 & 0.175 & 0.0180 \\
Mar & 0.084 & 0.385 & 1.640 & 0.101 & 1.917 & 0.053 & 0.0072 \\
Apr & 0.064 & 0.515 & 1.405 & 0.160 & 0.579 & 0.562 & 0.0075 \\
May & 0.097 & 0.318 & 1.472 & 0.141 & 1.252 & 0.210 & 0.0125 \\
Jun & 0.061 & 0.532 & 1.120 & 0.262 & 0.508 & 0.612 & 0.0057 \\
Jul & 0.002 & 0.994 & 0.552 & 0.581 & 0.011 & 0.991 & 0 \\
Aug & 0.064 & 0.511 & 1.305 & 0.192 & 0.598 & 0.549 & 0.0043 \\
Sept & 0.113 & 0.245 & 1.573 & 0.116 & 1.162 & 0.245 & 0.0083 \\
Oct & 0.018 & 0.859 & 0.552 & 0.581 & 0.179 & 0.858 & 0.0018 \\
Nov & 0.037 & 0.709 & 0.552 & 0.581 & 0.374 & 0.709 & 0.0031 \\
Dec & 0.069 & 0.475 & 0.869 & 0.384 & 0.715 & 0.475 & 0.0091 \\
Annual & 0.011 & 0.916 & 0.452 & 0.651 & 0.136 & 0.892 & 0.0021 \\
\hline
\end{tabular}

*Represents the trend is significant at 0.05 level

TABLE 6. Result for the pre-whitenning, trend free pre-whitening and variance correction and Sen's slope at 95\% confidence level $(\alpha=0.05)$ for monthly streamflow at Kajang station

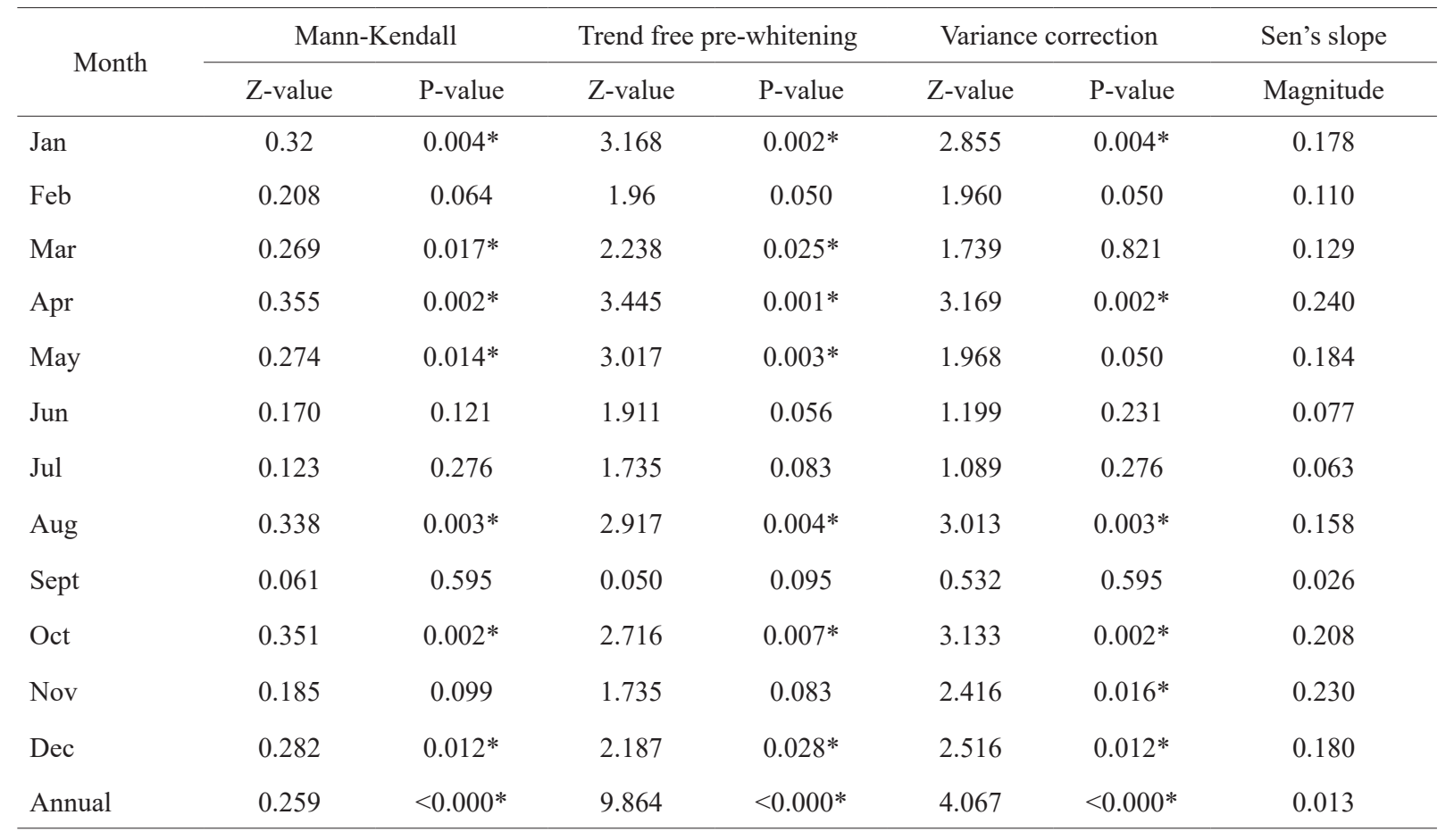

*Represents the trend is significant at 0.05 level 


\section{SEN'S SLOPE ANALYSIS}

The Sen's slopes for the monthly streamflow at the Lui and Kajang stations are shown in Figure 7. On a monthly scale, both stations shown in increasing trend for all months. For Lui station, the trend magnitude for each month varies from 0.009 to $0.018 \mathrm{~m}^{3} / \mathrm{s}$; this trend magnitude is very small compared to that for Kajang station. Kajang station shows the highest increase in trend magnitude $\left(0.23 \mathrm{~m}^{3} / \mathrm{s}\right)$ for November. This result is equivalent to findings presented in Figure 2 where the highest streamflow is also for the month of November. The months of June, July and September exhibited a small increasing of trend magnitude with values of $0.077,0.063$ and $0.026 \mathrm{~m}^{3} / \mathrm{s}$, respectively. Ebrahimian et al. (2018) carried out a similar study of the Sen's slope in the Sungai Langat Basin by using a different time period and found that the streamflow magnitude for the period between 1980 and 2010 is slightly higher compared to that in the current study.
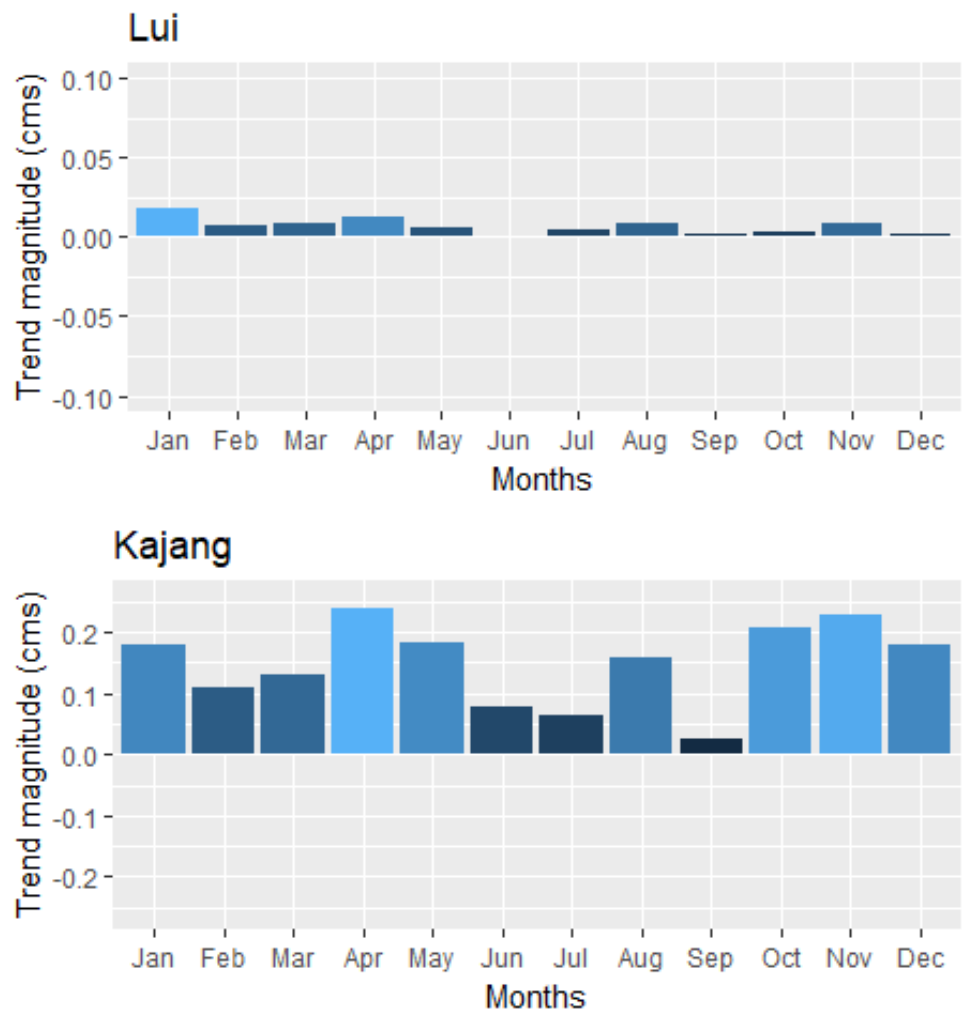

FIGURE 7. Trend magnitude for the monthly streamflow time series at Lui and Kajang stations

\section{INNOVATIVE TREND ANALYSIS METHOD}

The innovative trend method (ITM) was applied to the monthly streamflows of Sungai Lui and Sungai Kajang. This non-parametric method was proposed by Sen (2012) to detect the existence of trend in the time series. The result for ITM is presented in Figure 8, which shows the trend graphs of the monthly streamflow at Lui and Kajang stations. The monthly streamflow data are divided into three groups: low, medium and high. In Lui station, the low streamflow $\left(<4 \mathrm{~m}^{3} / \mathrm{s}\right)$ did not show a significant trend since the data points fall on the 1:1 line. The medium streamflow (between 4 and $8 \mathrm{~m}^{3} / \mathrm{s}$ ) shows a slightly increasing trend, while the high streamflow $\left(>8 \mathrm{~m}^{3} / \mathrm{s}\right)$ show a slightly decreasing trend. Generally, the trend for Lui station ranges from weak to no trend since most of the points are concentrated close to the 1:1 line. For Kajang station, the low, medium and high groups show increasing trend since most of the data deviated significantly from the 1:1 line. 
Lui River

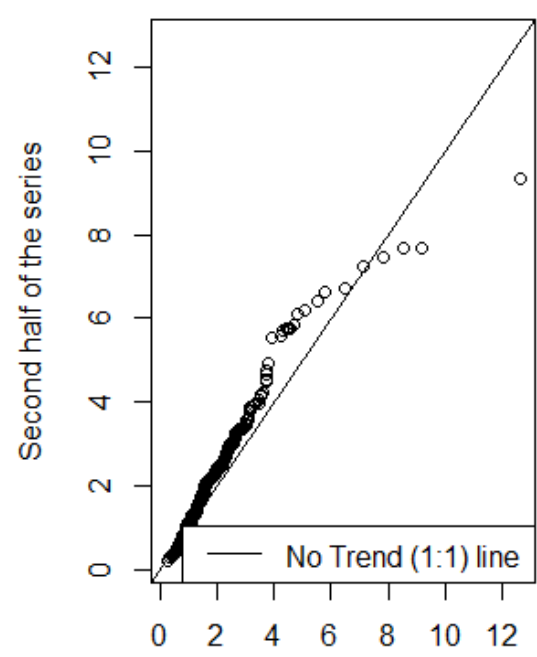

First half of the series

\section{Kajang River}

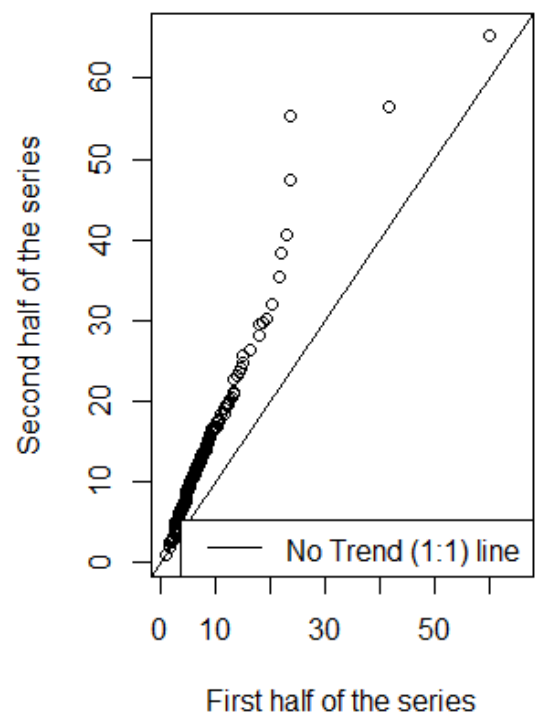

FIGURE 8. Innovative trend analysis of the data for Lui station (left) and Kajang station (right)

Sungai Langat is one of the longest rivers in Selangor, where the river runs from the north-east to south-west, which is from Sungai Lui Village to Dengkil. Sungai Langat has been experienced frequent flood and flash flood due to insufficient channel capacity. The heavy downpour and obstructed water flow at Sungai Langat are the major cause of flooding. The biggest flood was recorded in September 1982, with the flooded area of about $3.0 \mathrm{~km}^{2}$ and to a depth of $4.33 \mathrm{~m}$, and the damage at the flooded area was quite severe (Mohammed et al. 2011). Sungai Langat Basin also experienced rapid development in agriculture, urbanization, and industrialization. The changes of undeveloped to developed area may contribute the changes of discharge and direct runoff volume into Sungai Langat (Juahir et al. 2010).

The trend analyses in this study are used to evaluate the relationship between the trend of streamflow and land used at different sub-basin. Five different methods were used to access the significance of trends which are MannKendall trend test, TFPW, Variance correction, Sen's slope, and Innovative trend analysis. The Kajang station show increasing streamflow compares to Lui station. Study done by Juahir et al. (2010) also found that no significant trend is observed for Lui station. According to Booij et al. (2019), land used activities such as deforestation and wetter climate can increase the annual streamflow. Other than that, the agricultural development also can contribute to streamflow changes (Levy et al. 2018). Since Malaysia's climate is being hot and humid throughout the year, also being exposed by monsoon seasons, it can contribute to streamflow changes. The Kajang sub-basin area has been transformed into an urban area and also converted into agricultural development. Whereas the Lui sub-basin has less percentage of land used changes. Loss of forests can lead to increased water run-off (Greenpeace Research Laboratories 2013). The deforestation can decrease the evapotranspiration process, which could increase localized run-off and raise river levels. These impacts could contribute towards flooding, especially in the wet season.

\section{CONCLUSION}

This study used the historical streamflow data from two gauging stations in the Sungai Langat Basin to analyse the streamflow trend at both stations. The data were taken from the daily streamflow record and was converted into monthly data.

The two flow stations involved in this study are Sungai Lui and Sungai Kajang; the records from these stations span a period of more than 30 years. The result for the modified Mann-Kendall trend test after considering serial independence effect shows that the mean for the 
monthly time series data for Sungai Lui has a significantly increasing trend only for January when using trend free pre-whitening (TFPW) method, while the result for the variance correction method show that there is no significant trend of each months. The streamflow magnitude for Sungai Lui established using the Sen's slope estimator is very small and ranged between 0.009 and $0.018 \mathrm{~m}^{3} / \mathrm{s}$. The result for the variance correction method showed that Sungai Kajang has a significantly increasing trend for January, April, August, October, November, and December while according the Sen's slope estimator the month of November showed the highest increasing trend magnitude of $0.23 \mathrm{~m}^{3} / \mathrm{s}$. The results for innovative trend method (ITM) for Sungai Kajang showed an increasing trend for the low, medium and high value groups, while the trend for Sungai Lui ranged from weak to no trend.

The results for the Mann-Kendall and innovative trend methods are similar for both Sungai Lui and Sungai Kajang. The significantly increasing trend in the streamflow of Sungai Kajang was closely related to elevation, variation in landscape metrics, and the change in land use. The streamflow trend for Sungai Lui is essentially insignificant, thus indicating that there is not enough evidence to indicate a significant change in the hydrological series.

\section{ACKNOWLEDGEMENTS}

The authors would like to thank the Earth Observation Centre, Universiti Kebangsaan Malaysia and the Department of Irrigation and Drainage (DID), Ministry of Natural Resources and Environment, Malaysia for providing the data for this research. The authors wish to express their gratitude to the Government grant GUP2020-013 for funding this research.

\section{REFERENCES}

Amirabadizadeh, M., Huang, Y.F. \& Lee, T.S. 2015. Recent trends in temperature and precipitation in the Langat River Basin, Malaysia. Advances in Meteorology 2015: 579437.

Ay, M. \& Kisi, O. 2015. Investigation of trend analysis of monthly total precipitation by an innovative method. Theoretical and Applied Climatology 120(3-4): 617-629.

Azam, M., Maeng, S.J., Kim, H.S., Lee, S.W. \& Lee, J.E. 2018. Spatial and temporal trend analysis of precipitation and drought in South Korea. Water 10(6): 765.

Bayazit, M. \& Önöz, B. 2009. To prewhiten or not to prewhiten in trend analysis? Hyrological Sciences 52(4): 611-624.

Booij, M.J., Schipper, T.C. \& Marhaento, H. 2019. Attributing changes in streamflow to land use and climate change for 472 catchments in Australia and the United States. Water 11(5): 1059.

Chattopadhyay, S. \& Edwards, D.R. 2016. Long-term trend analysis of precipitation and air temperature for Kentucky, United States. Climate 4(1): 10.
Chen, Y., Guan, Y., Shao, G. \& Zhang, D. 2016. Investigating trends in streamflow and precipitation in Huangfuchuan basin with wavelet analysis and the Mann-Kendall test. Water 8(3): 77.

Cristina, L., Dias, P., Macedo, M.N., Heil, M., Coe, M.T. \& Neill, C. 2015. Regional studies effects of land cover change on evapotranspiration and streamflow of small catchments in the Upper Xingu River basin, Central Brazil. Journal of Hydrology: Regional Studies 4(Part B): 108-122.

da Silva, R.M., Santos, C.A.G., Moreira, M., Corte-Real, J., Silva, V.C.L. \& Medeiros, I.C. 2015. Rainfall and river flow trends using Mann-Kendall and Sen's slope estimator statistical tests in the Cobres River basin. Natural Hazards 77(2): 1205-1221.

Diop, L., Yaseen, Z.M., Bodian, A. \& Djaman, K. 2017. Trend analysis of streamflow with different time scales: A case study of the upper Senegal River. ISH Journal of Hydraulic Engineering 5010: 1-10.

Ebrahimian, M., Nuruddin, A.A., Amin, M., Soom, M., Sood, A.M. \& Neng, L.J. 2018. Trend analysis of major hydroclimatic variables in the Langat River basin, Malaysia. Singapore Journal of Tropical Geography 39(2): 192-214.

Gavrilov, M.B., Tošić, I., Marković, S.B., Unkašević, M. \& Petrović, P. 2016. Analysis of annual and seasonal temperature trends using the Mann-Kendall test in Vojvodina, Serbia. Quarterly Journal of the Hungarian Meteorological Service 120(2): 183-198.

Greenpeace Research Laboratories. 2013. An Impending Storm Impacts of Deforestation on Weather Patterns and Agriculture. Amsterdam: Greenpeace International.

Hajani, E., Rahman, A. \& Ishak, E. 2017. Trends in extreme rainfall in the State of New Trends in extreme rainfall in the State of New South Wales, Australia. Hydrological Sciences Journal 62(13): 2160-2174.

Hamed, K.H. \& Ramachandra, R. 1998. A modified MannKendall trend test for autocorrelated data. Journal of Hydrology 204(1-4): 182-196.

Hamzah, F.M., Yusoff, S.H.M. \& Jaafar, O. 2019. L-momentbased frequency analysis of high-flow at Sungai Langat, Kajang, Selangor, Malaysia. Sains Malaysiana 48(7): 1357 1366.

Hamzah, F.M., Saimi, F.M. \& Jaafar, O. 2017. Identifying the monotonic trend in climate change parameter in Kluang and Senai. Sains Malaysiana 46(10): 1735-1741.

Jan, N.A.M., Shabri, A., Hounkpe, J. \& Badyalina, B. 2018. Modelling non-stationary extreme streamflow in Peninsular Malaysia. International Journal of Water 12(2): 116-140.

Juahir, H., Zain, S.M., Aris, A.Z., Yusof, M.K., Armi, M., Samah, A. \& Mokhtar, M. 2010. Hydrological trend analysis due to land use changes at Langat River basin. Environment Asia 3(Special Issue): 20-31.

Kendall, M.G. 1957. Rank Correlation Methods. 4th ed. London: Charles Griffin.

Kisi, O., Santos, C.A.G., Silva, R.M. \& Zounemat-Kermani, M. 2018. Trend analysis of monthly streamflows using Şen's innovative trend method. Geofizika 35: 53-68.

Levy, M.C., Lopes, A.V., Cohn, A., Larsen, L.G. \& Thompson, S.E. 2018. Land use change increases streamflow across the arc of deforestation in Brazil. Geophysical Research Letters 45(8): 3520-3530. 
Mayowa, O.O., Pour, S.H. \& Shahid, S. 2015. Trends in rainfall and rainfall-related extremes in the east coast of peninsular Malaysia. Journal of Earth System Science 124(8): 16091622.

Memarian, H. \& Balasundram, S.K. 2016. Hydrological trend analysis integrated with landscape analysis at the watershed scale (case study: Langat basin, Malaysia). In Landscape Ecology - The Influences of Land Use and Anthropogenic Impacts of Landscape Creation. London: IntechOpen. pp. 61-84.

Mohammed, T.A., Al-Hassoun, S. \& Ghazali, A.H. 2011. Prediction of flood levels along a stretch of the Langat River with insufficient hydrological data. Pertanika Journal of Science and Technology 19(2): 237-248.

Mustapha, A. 2013. Detecting surface water quality trends using Mann-Kendall tests and Sen's slope estimates. International Journal of Advanced and Innovative Research 2: 108-114.

Önöz, B. \& Bayazit, M. 2003. The power of statistical tests for trend detection. Turkish Journal of Engineering and Environmental Sciences 27(4): 247-251.

Oztopal, A. \& Sen, Z. 2017. Innovative trend methodology applications to precipitation records in Turkey. Water Resources Management 31(3): 727-737.

Palizdan, N., Falamarzi, Y., Huang, Y.F., Lee, T.S. \& Ghazali, A.H. 2015. Temporal precipitation trend analysis at the Langat River basin, Selangor, Malaysia. Journal of Earth System Science 124(8): 1623-1638.

Palizdan, N., Falamarzi, Y., Huang, Y.F., Lee, T.S. \& Ghazali, A.H. 2014. Regional precipitation trend analysis at the Langat River. Theoretical and Applied Climatology 117(34): 589-606.

Piyoosh, A.K. \& Ghosh, S.K. 2017. Effect of autocorrelation on temporal trends in rainfall in a valley region at the foothills of Indian Himalayas. Stochastic Environmental Research and Risk Assessment 31(8): 2075-2096.

Rahman, M.A., Yunsheng, L. \& Sultana, N. 2017. Analysis and prediction of rainfall trends over Bangladesh using Mann-Kendall, Spearman's rho tests and ARIMA model. Meteorology and Atmospheric Physics 129(4): 409-424.

Rao, A.R., Azli, M. \& Pae, L.J. 2011. Identification of trends in Malaysian monthly runoff under the scaling hypothesis. Hydrological Sciences Journal 56(6): 917-929.

Rim, C. 2017. Implications of geographical factors and trends of climatic factors on aridity/humidity trends. Journal of Scientific Research \& Reports 17(6): 1-11.

Sa, Z., Ismail, T., Sung, E., Xiao, C. \& Wang, J. 2017. Trends analysis of rainfall and rainfall extremes in Sarawak, Malaysia using modified Mann-Kendall test. Meteorology and Atmospheric Physics 131(3): 263-277.

Sagarika, S., Kalra, A. \& Ahmad, S. 2014. Evaluating the effect of persistence on long-term trends and analyzing step changes in streamflows of the continental United States. Journal of Hydrology 517: 36-53.

Salman, S.A., Shahid, S., Ismail, T., Chung, E. \& Al-abadi, A.M. 2017. Long-term trends in daily temperature extremes in Iraq. Atmospheric Research 198: 97-107.

Samsudin, M.S., Khalit, S.I., Juahir, H., Fahmi, M. \& Nasir,
M. 2017. Application of Mann-Kendall in analyzing water quality data trend at Perlis, Malaysia. International Journal on Advanced Science, Engineering and Information Technologi 7(1): 78.

Sen, P.K. 1968. Estimates of the regression coefficient based on Kendall's Tau. Journal of the American Statistical Association 63(324): 1379-1389.

Sen, Z. 2014. Trend identification simulation and application. Journal of Hydrologic Engineering 19(3): 635-642.

Sen, Z. 2012. Innovative trend analysis methodology. Journal of Hydrologic Engineering 17(9): 1042-1046.

Sulaiman, N.H., Kamarudin, M K.A., Mustafa, A.D., Amran, M.A., Azaman, F., Abidin, I.Z. \& Hairoma, N. 2015. Analisis corak sungai Pahang menggunakan kaedah bukan parametrik: Ujian corak Mann Kendall. Malaysian Journal of Analytical Sciences 19(6): 1327-1334.

Terzioglu, Z.O., Kankal, M., Yuksek, O., Nemli, M.O. \& Akcay, F. 2019. Analysis of the precipitation intensity values of various durations in Trabzon Province of Turkey by Sen's innovative trend method. Sigma Journal of Engineering and Natural Sciences 37(1): 241-250.

Thenmozhi, M. \& Kottiswaran, A.V. 2016. Analysis of rainfall trend using Mann-Kendall test and the Sen's Slope estimator in Udumalpet of Tirupur district in Tamil Nadu. International Journal of Agricultural 6(2): 131-138.

Wang, C., Shang, S., Han, Y., Sauvage, S., Sanchez-Perez, J.M., Kuramochi, K. \& Hatano, R. 2018. Integrated Effects of land use and topography on streamflow response to precipitation in an agriculture-forest dominated northern watershed. Water 10(633): 633.

Yang, H.W., Jaafar, O., El.-Shafie, A. \& Sharifah Mastura, S.A 2011. Analysis of hydrological processes of Langat River sub basins at Lui and Dengkil. International Journal of the Physical Sciences 6(32): 7390-7409.

Yue, S., Pilon, P., Phinney, B. \& Cavadias, G. 2002. The influence of autocorrelation on the ability to detect trend in hydrological series. Hydrological Processes 16(9): 18071829.

Yue, S. \& Wang, C.Y. 2002. Applicability of prewhitening to eliminate the influence of serial correlation on the MannKendall test. Water Resources Research 38(6): 41-47.

Zhang, S., Lu, X.X., Higgitt, D.L., Chen, C.T.A., Han, J. \& Sun, H. 2008. Recent changes of water discharge and sediment load in the Zhujiang (Pearl River) basin, China. Global and Planetary Change 60(3-4): 365-380.

Zhao, J., Huang, Q., Chang, J., Liu, D., Huang, S. \& Shi, X. 2015. Analysis of temporal and spatial trends of hydro-climatic variables in the Wei River basin. Environmental Research 139: 55-64.

Siti Hawa Mohd Yusoff, Firdaus Mohamad Hamzah*, Othman Jaafar \& Hazrina Tajudin

Department of Civil and Structural Engineering

Faculty of Engineering and Built Environment

Universiti Kebangsaan Malaysia

43600 UKM Bangi, Selangor Darul Ehsan

Malaysia 
Siti Hawa Mohd Yusoff

Department of Science and Biotechnology

Faculty of Engineering and Life Sciences

Universiti Selangor

45600 Bestari Jaya, Selangor Darul Ehsan

Malaysia
*Corresponding author; email: fir@ukm.edu.my

Received: 27 May 2020

Accepted: 8 August 2020 